\begin{tabular}{c|l|l|l} 
Case Reports $h$ & Case Rep Dermatol 2010;2:146-148 & Published online: August 19, 2010 & $\begin{array}{l}\text { @ 2010 S. Karger AG, Basel } \\
\text { ISSN 1662-6567 } \\
\text { Www.karger.com/cde }\end{array}$ \\
\hline Dol: $10.1159 / 000319792$ & & & \\
\hline
\end{tabular}

\title{
Dermoscopy of Pitted Keratolysis
}

\author{
Lauren L. Lockwood Samuel Gehrke \\ Alexander A. Navarini \\ Department of Dermatology, University Hospital of Zurich, Zurich, Switzerland
}

\section{Key Words}

Pitted keratolysis - Corynebacteria infections - Keratolysis plantare sulcatum . Hyperhidrosis

\begin{abstract}
Irritated hyperhidrotic soles with multiple small pits are pathognomonic for pitted keratolysis (PK). Here we show the dermatoscopic view of typical pits that can ensure the diagnosis. PK is a plantar infection caused by Gram-positive bacteria, particularly Corynebacterium. Increases in skin surface $\mathrm{pH}$, hyperhidrosis, and prolonged occlusion allow these bacteria to proliferate. The diagnosis is fundamentally clinical and treatment generally consists of a combination of hygienic measures, correcting plantar hyperhidrosis and topical antimicrobials.
\end{abstract}

\section{Case Report}

A 32-year-old Caucasian woman presented with irritated soles, revealing multiple small blackish pits (fig. 1a, magnification by dermatoscope in b) and hyperhidrosis. Clinical presentation of chronic, acquired small pits on the weight bearing areas of the soles, associated with occluding footwear and hyperhidrosis, is pathognomonic for pitted keratolysis (PK) [1]. PK is caused by a cutaneous infection with Gram-positive bacteria, particularly Corynebacterium and a number of other species of normal skin flora. Increases in skin surface $\mathrm{pH}$, hyperhidrosis, and prolonged occlusion allow these bacteria to proliferate, producing two keratin-degrading enzymes, serine proteases P1 and P2, which create pits by locally dissolving the stratum corneum's corneodesmosomes and keratohyalin granules [2]. The infection is confined to the plantar stratum corneum, does not impede patient activity but often presents with unpleasant symptoms such as malodor, pain and irritation. Although histology was proposed as a sensitive diagnostic method [6], the diagnosis is fundamentally clinical. PK can be found in association with other Corynebacterium infections, like erythrasma and trichomycosis axillaris $[7,8]$. Treatment generally consists of a combination of hygienic measures and antimicrobials. PK can occasionally be misdiagnosed as a mycotic infection, and patients can present with ineffective previous antimycotic treatment. No large prospective randomized studies have been performed concerning therapy for PK. Antimicrobials to reduce corynebacterial growth are the therapeutic mainstay, with topical or systemic erythromycin or imidazole derivatives $[3,4]$. It has been proposed that keratolytic products reducing the bacteria's habitat may be beneficial [4]. Decreasing sweat production by topical aluminum hydroxide should be considered, and even botulinum toxin has been used in two patients 
with refractory PK due to prominent hyperhidrosis [5]. Socks and shoes should be changed regularly. Washing at $>60^{\circ} \mathrm{C}$ inactivates corynebacteria. Antibacterial washing solutions are not evidence-based, but usually recommended. Occupational shoes should be ventilated properly, but these recommendations are usually difficult to implement in the workplace [4]. Reduction of friction to avoid hyperkeratosis, which represents the substrate that the corynebacteria can thrive on, is achieved by fitting shoes properly. Here we advised the patient to wear non-occlusive footwear and use aluminum hydroxide $20 \%$ lotion for the plantar hyperhidrosis. In addition, a topical erythromycin gel was prescribed.

Fig. 1. a Multiple 2-3 mm crater-like shallow plantar pits. b Dotted line indicates magnified area in inset: $10 \times$ dermoscopic magnification revealing heterogeneous architecture of the pit walls according to random dissolution of stratum corneum by bacterial colonies.

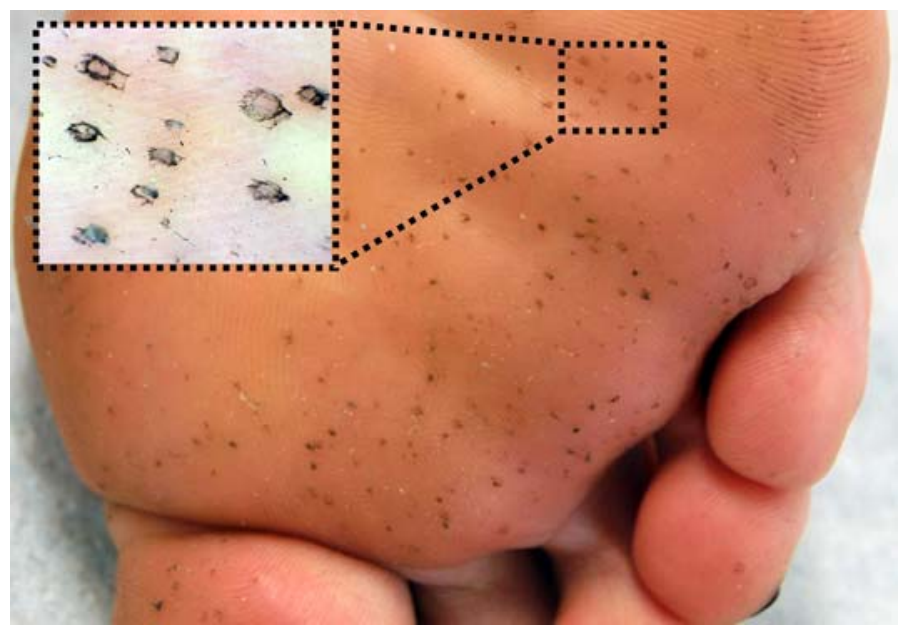




\section{References}

1 Takama H, Tamada Y, Yano K, Nitta Y, Ikeya T: Pitted keratolysis: clinical manifestations in 53 cases. Br J Dermatol Aug 1997;137:282-285.

2 Hermanns-Le T, Garcia R, Arrese JE, Pierard GE: Pitted Keratolysis: new ultrastructural insight in keratohyalin granule and corneodesmosome alterations. Exog Dermatol 2004;3:107-111.

-3 Feingold DS, Hirschmann JV, Leyden JJ: Bacterial infections of the skin. J Am Acad Dermatol Mar 1989;20:469-475.

-4 Blaise G, Nikkels AF, Hermanns-Le T, Nikkels-Tassoudji N, Pierard GE: Corynebacterium-associated skin infections. Int J Dermatol 2008;47:884-890.

-5 Tamura BM, Cuce LC, Souza RL, Levites J: Plantar hyperhidrosis and pitted keratolysis treated with botulinum toxin injection. Dermatol Surg 2004;30:15101514.

-6 Wohlrab J, Rohrbach D, Marsch WC: Keratolysis sulcata (pitted keratolysis): clinical symptoms with different histological correlates. Br J Dermatol 2000;143:1348-1349.

7 Shelley WB, Shelley ED: Coexistent erythrasma, trichomycosis axillaris and pitted keratolysis: an overlooked corynebacterial triad? J Am Acad Dermatol 1982;7:752-757.

8 Rho NK, Kim BJ: A corynebacterial triad: Prevalence of erythrasma and trichomycosis axillaris in soldiers with pitted keratolysis. J Am Acad Dermatol 2008;58(2 suppl):S57-S58. 